46. Strümpell. Pernicious Anemia. Textbook, 1897, ii, 513-517. 47. Strümpell. Leukämje u. Pseudoleukämie. Textbook, 1897 , ii, 532-534.

25. Taylor. A Case of Splenic Anemia or Primary Splenomegaly. Guy's Hospital Report, London, 1896, lii, 173.

- Taylor. Discussion on Anemia. British Medical Journal

1896, ii, 719-728.
29. Terrile. Un caso di Splenomegalia Primitiva. Gazz. d. osp.

Milano, 1896, xvii, 904 .
5. Wells. (Case of Splenectomy.) Gaz. Hebdomadaire, 1866, p

23. West. Splenic Anemia. Medico-Chirurgical Transactions, 1. West. Splenic Anemia. Allbutt's System of Medicine, v,

21. Williamson. Cases of Anemia with Great Enlargement of the Spleen, ete. Medical Chronicle. Manchester, 1893, xviii,

Wood. Relation of Leukemia to Pseudoleukemia. American Journal Medical Sciences, 1871, p. 373.

48. Ziegler. Milz. Path. Anat., 1898. Spec. Anat., ii.

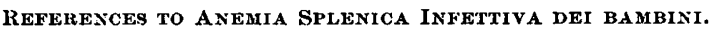
(ANEMIA SPLENICA INEANTILE.)

53. Cardarelli. Nosografia della Pseudoleucemia Splenica (Infettiva) dei bambini. Bolle. della R. Accad. méd. Chir. di Napoli, 1690, ii, 17-44. (No other reference in Index Medicus.)

Carr. Enlargement of the Spleen in Young Children. Transactions Medical Society, London, 1891-2, xV, 245; Lancet London, 1892, i, $\$ 07-963$.

51. Di Lorenzo. Contrib. alla casuistica e Clin. dell' Anemia Splenica Infettiva dei bambini. Arch. Ital, di Pediat., Napoli, 1890, viii, 175-188.

52. Fédé. Sull' Anemia Splenica Infettiva dei bambini. Boll ella R. Accad. méd. Chir. di Napoli, 1889, i, 168-173.

57. (See Somma and Fédé.)

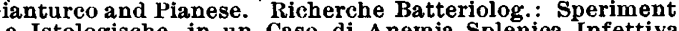
e Istologische in un Caso di Anemia Splenica Infettiva.

62. Gossage. Splenic Anemia. Westminster Hospital Report, London, 1895 , ix, 50

61. Hock u. Schlesinger. Hämatologische Studien. Beitr. zur Kinderheilk, 1892

58. Mensi. Morbo Splenico d. Henoch. o. Anemia Splenica Infantile. Gior. della R. Accad. di méd. di Torino, 1891, xxxix,

59. Mensi. Nuovo Contrib. allo Studio della Pseudoleucemia Infantile. Riforma Medica, 1892, No. 133 (abs. Schmidt's fantile. Riforma Medica, 1892, No. 133 (abs. Schmidt's Michaelis. Ueber Chron. 1883. Plötz, $26,8^{\circ}$

63. Mya. Un Caso di Anemia Splenica Infantile, etc. Clin. Mod., Hirenze, 189t; ii, $1-3$

co. Mya and Trambusti. Contrib. allo Studio dell' Anemia Splenica Infantile. Speriment., mem. orig. Firenze, 1892, 359388.

55. Porter. Enlarged Spleen. British Medical Journal, 1885, i,

Somma and Fédé. Dell' Anemia Splenica Infettiva de ambini. Areh. Ital. di Pediat., 1896, p. 2\&5; Atti. del Primo Cong. Pediat. Ital. Roma, 1890.

50 (L.) Somma. Sull' Anemia Splenica Infantile. Arch. di Patolo gia Infantile, 1884, ii, 1 .

64. Thistle. Splenic Anemia. Canada Practice and Review, 1899 XXv. ‘23.

References to Anema Infantum Pseudoleukemica.

72. Alt $u$. Weiss. Anemia Infantum Pseudoleukemica. Centrbl f. die Med. Wiss., 1892, xxx, 433-450.

76. Andeoud. Note sur l'anemié Pseudoleucémique du premier age. Rev. méd. de la Suisse, 1894, xiv, 507-516.

69. Bayinsky. Fünf. Fälle Pseudoleukämische Erkrankung. Arch. $f$. Kinderheilk, 1891, xiii, 304-311.

79. Fischl. Zur Histologie des Kindlichen Blutes. Zeitschr. f Heilkunde, Bd. xiii, 1892.

80. Fischl. über Anemia Infantum Pseudoleucemica. Prag. Med. Woch., 1894, xix, 43.

81. - (Discussion of Fischl's Paper.) Prag. Med. Woch., 1894, xix.

82. Fischl u. Siegert. $\ddot{u}$ die Anemien im Frühen Kindesalter. Münch. Med. Woch., 1898. (Conclusions.)

Munch. i die An ̈amien im friihen Kindegalter. Jahrb.

87. Fox and Ball, On Hypertrophy of the Spleen

British Medical Journal, London, 1892, i, 851-856. Gockner. Zur Casuistik der Anemia Infantilis Psendoleucemia. Münch., 1895; J. F. Let

73. Hock u. Schlesinger. Hämatologische Studien. Beitr. zur Kinderheilk., 1892. (Franz Deuticke. Wien.)

70. Holt. Pernicious Anemia in Child Two Years Old with Immense Spleen, etc. Medical Record, New York, 1891, xxxix, 410.

66. von Jaksch. Ueber Leukemie u. Leukocytose im Kindesal ter. Wien. klin. Woch., 1888.

67. von Jaksch. uiber Diag. u. Therap. d. Krankh. des Blutes. Prag. Med. Woch., 189.

74. Koplik. Anemia Infantum Pseudoleukemica. Arch. Pediat. $1893, x, 210-215$

85. Kuttner. uber das Vorkommen von Milztumoren bei Kindern besond. bei Rachitischen. Berl. klin. Woch., 1892, xxix, 1,106-37.

- Loos. ud. Veränderungen d. Morphologischen Bestandtheile d. Blutes bei Verschiedennen Krankheiten der Kinder. Jahrb. f. Kinderheilk, 1895, x xxix, 331

68. Luzet. Anémies de la Premiére Enfance. Thésè, Paris, 1891 (G. Steinheil).

Monti. uber Anemien im. Kindesalter. Wien. Med. Woch 1894, xlív.
75. Monti u. Berggriun. Die Chronische Anämie im Kindesalter. Leipzig; Verlag von F. C. W. Vogel, 189:.

(am Kindesalter. Berl. klin. Woch., 1882, xix, 533-536.

- Siegert. iu. die Anemien im. frühen Kindesalter. Jahrb. f. Kinderheilk, 1899. (Complete article.)

6. von Starck. uber der l3edeutung des Milztumors bei Rachitis. Deutsch. Arch. f. klin. Med., 1896, Ivii, 265-278.

3. Stengel. Anemia Infantum Pseudoleukemica. Twentieth

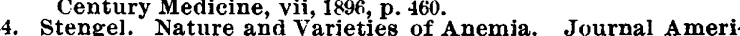
can Medical Association, 1897.

1. Tissier. De la Pseudoleucémie. Gas. d. Hôp., Paris, 1892, lxv, 789-795.

ickery. Anemia with Enlarged Spleen. Medical News,

General References.

['The following articles were not referred to in the text, because for the most part they bore but a general relation to the subject that were considered. Two or three articles which contained nothing new about splenic anemia were not referred to from lack of space.]

uerbach. Neuere Arbeiten aus dem Gebiete d. Phys. u. Path. des Blutes. Schmidt's Jahrb., 1899, celxi; 1900, celxv.

Barbier. Pathogénie et Nature Infectieuse de la lymphadenie etc. Gaz Hebdomadaire No.5. 1804. (Abs Virehow's Jahresbericht, 1895, ii,

Barbrock. üeber Pseudoleukämie mit recurrierenden Fieberver lauf. Kiel, 1890; A. F. Jensen, xxv, $8^{\circ}$.

lauf. Kiel, 1890; A. F. Jensen, xx , Children, $1 \times 89$, if 231 .

çon. Maladies du Sang et des organes Hématopoietique, etc. Arch. gén. de méd., Paris, 190i, N. S. iii, 488, 510.

Brückner. Neuere Arbeiten aus dem Gebiete d. Phys. u. Path. des Blutes. Schmidt's Jahrb.,1897, celv.

D'Espine et l'icot. Man. des Maladies de l'Enfance, 1894

Drummond. On Splenic Disease in Infants. Medical Times and Gazette, London, 1880, ii, 147,

Gazette, London, 1880, ii, 147, Woch., 1893, xliii, 285, 3*1, 384, 422 .

Gabbi. ü. Norm. Hämatolyse mit besond. Berucks. d. Hämatolyse d. Milz. Beitr. zur Path. Anat. u. zur Allg. Path. Zena. 1893 , xiv, 351-369.

Grawitz. $\ddot{\mathrm{u}}$ Begriffs bestimmung; Ursach : etc. d. Perniciösen Anämie. Ber sion, 716 -730.

Griffith. Keating's Cyclopedia of Diseases of Children, 1890

Hayem. Note sur l'anémie des nourissons. Gaz. Hebd. de méd. Paris, 1889, xxvi, 726; Gaz. d. Hop., Paris, 1889, lxii, 1,183; Bull. et mem. Soc. méd. d. Hòp, 1889 , iii, S. vi, 454 .

in. Anäm. Splen. Pseudoleuk. Berl. klin. Woch., 1897, xxxiv, 713-716.

Kundrat. uber Lymphosarcomatosis. Wien. klin. Woch., 1898 , pp. 211-234

pp. 211-234. Gustav Fischer.

Litten. Die Krankheiten der Milz. Nothnagel Spec. Path. u. Therap., 1898, viii.

r. Diseases of the Spleen. Ziemssen Cyclopedia of the Practice of Medicine, 1878.

Leukämie u. Pseudoleukämie. Wien. klin. Woch., 1890 iii, 697. (Continued.)

rd. Diseases of the Blood. American Textbook of Disease of Children, 1894, p. 375 .

Paltauf. Sammel referate u. Lymphosarkom. Lubarsch. Ergeb. d. Allg. Path. u. Path. Anat., 1896.

ta to A ttuale degli Studi Sull An. Splen. Infett. dei bambini. La Pediat., 1898, p. 3 .

Pianese. Colorozione del Microrganismo dell' Anemia Splenica con metodo speciale. Gior. Internaz. d. Sc. Med., Napoli, 1894, N. S. Xvi, 697

Reinert. Die Zähling des Blutkörperchen. Leipzig. Vogel, 1891. Ribbert. Milz. Path. Histol., 1896.

Rosenstein. Zur Sogenannten Pseudoleukämie. Arch. f. Path.

Roy. Physiology and Pathology of Spleen. Journal Physiology, London, $1881-2$, iii, 203.

Sternberg. Sammel referate univer primärerkrank d. Lymphatisch Apparates. Centrbl. f. d. Grenzgeb. d. Med. u. Chir. 1899 , ii.

Van Noorden. Untersuchungen uber Schwere Anamien. Char. Annalen, Berlin, 189:2, xvii, 202

Verdelli. Sull' Etiolog, della Pseur Arch. Ital. di Clinica Med., i, 32-4, 1894. (Abs. Virchow's Jahresbericht, 1895, ij, xxix.)

der Pseudoleukämie. Deutsch. Arch. f. klin. Med., 1892-3, li, 83-126.

\section{A CASE OF ANOMIA AND PARAPHASIA.}

BY GEO. H. THOMAS, A.M., M.D., KAXSAS CITY, MO.

The following is the report of a case of peculiar interest ; in the first place because of its rarity, and in the second place because it adds a little more to our knowledge of the cerebral localization of that form of aphasia known as anomia, or 
the inability to recall the names of objects. Dr. ments of more complicated nature than those of G. H. Hammond, in the Medical Record of Dec. the day before. These documents, it may be well 9, 1900, reports 2 cases, and Dr. Edwin E. Jack, to state here, were examined after his death, and in the Boston Medical and Surgical Sournal of were found to be carefully written and correct in Dec. 6, 1900, reports another. These 3 cases, every way.

though differing in many particulars from each other, and from the one here to be described, show sufficient similarity to warrant their being included in one group. Previous to the appearance of the above, Dr. Mills reported a case in the Journal of Nervous and Mental Disease of 1895, which, together with those of Hammond and Jack, complete, so far as I know, the literature of the subject.

The patient about whom I am writing was a lawyer, 60 years of age, living in Kansas. He had been married many years; was the father of several healthy children, and, so far as could be learned, had never had any vencreal disease. He had all his life been very abstemious in his habits. His health had always been good, and, barring a discharge from his left ear of 20 years' duration, he always regarded himself as perfectly sound in every way.

A few months previous to the occurrence of the present illness, the patient had headaches for the first time in his life; and on one occasion, about 5 months before the present symptoms, he acted very strangely to his wife, using profane language to her, which he afterwards entirely forgot. This conduct was the more noticeable because he had never been known to use similar language before, and had always been a man of refined sensibilities, and one who showed especial fondness for his wife.

About 5 weeks before the writer saw the patient, he began to have intermittent attacks of headache, which were described as general, though the pain was most marked on the left side of the head. During the last 2 weeks these headaches became more severe, and were more or less persistent day and night, and finally were so troublesome that on Monday, Nov. 12, 1900, he was compelled to consult his family physician, Dr. B. F. Morgan of Clay Centre, Kan. The doctor found that the patient acted strangely, and had a noticeable difficulty in finding words to express himself. One thing especially noticed was that the patient on entering the office went to the stove, in which a hot fire was burning, and; stretching out his hands, asked if there were a fire in the stove. This question was repeated several times by the patient, although the doctor gave each time an affirmative answer. This queer conduct, the difficulty of speech and the headache, were the only symptoms manifested.

The doctor prescribed for him, with the effect of giving him a better night's rest than he had had for some time. The patient attended business the next day, and, although still complaining of his headache, was able to make out some legal documents relative to the sale of land. Throughout Tuesday night he suffered much with pain, but was able to attend business again on Wednesday. On this day he drew up other legal docu-

On Wednesday he called on Dr. Morgan again, when a more careful examination of his defective speech was made. In the process of conversation the patient mentioned the doctor's name several times, but when asked directly to repeat the name, was unable to do so. Several attempts to recollect the name of his law partner failed completely. The doctor, to test him, gave the names of a large number of neighboring lawyers, to all of which he shook his head, and evinced much annoyance that his memory was so poor.

On the following Sunday his physician, recognizing the probable nature of the trouble, brought him to Kansas City, where he was placed in Saint Margaret's Hospital, in the service of Dr. John W. Perkins, through whose courtesy I was asked to examine and give an opinion of the case on Monday, Nov. 19, 1900.

The patient was found in bed in dorsal decubitus and somnolent, probably partly due to a small dose of one-eighth of a grain of morphia, which he had received the evening before. From this state, however, he was easily aroused. He had passed a comparatively comfortable night, in spite of a journey of over 100 miles in a railroad train, but was still suffering from a diffuse headache, with a centre of greatest pain over the left side of the head. His face was thin, ashen gray, and his appearance was that of one suffering from sepsis, although he had no temperature. He looked his age, and his expression showed that he had undergone much pain, and that he was worried and anxious about himself. His breath was exceedingly offensive, and his tongue dry and heavily coated. Pulse was 90 and weak, and the temperature normal. The pupils reacted to light, but the left pupil was thought to be a little the smaller. Vision was good in both eyes; there was no limitation or other modification in the field of vision; and examination of the fundi was negative.

There were no motor or sensory disturbances anywhere in the body. There was no tremor of the tongue, nor in the extended fingers. Both knee jerks were present, though sluggish. There was no ankle clonus or other abnormal reflex. The co-ordination of the muscles was found unimpaired, and Romberg's symptom was absent. He could hear a watch tick at a distance of 4 feet with the right ear, but on the left side could hear it only in contact with the ear. There was a foulsmelling, purulent discharge from the left ear, but no tenderness over the mastoid. No cultures or microscopic examination of the discharge was made, because of its long standing. So far as the patient could remember, he had never had an earache, and wàs quite sure he had never had any soreness behind the ear.

The noticeable thing about the patient in talking with him was his paraphasia; that is, his miscalling names of things, and his replacing one 
word for another, as in the use of adjectives. $\mathrm{He}$ read aloud without mistakes, understood written and spoken words, wrote correctly from dictation, and was able to remember and write his name. But when shown any object and asked to name it, he found it impossible to do so, though he apparently recognized perfectly what the object was, and frequently indicated his knowledge by trying to show its use. A very large number of things were shown him, but with all of them there was the same inability as before. Whenever he miscalled the object, he knew his mistake at once, and after several attempts to give the correct name, gave up in despair. When the name of the object was suggested to him, he recognized it immediately, and was able to repeat it; but in a few moments, if the same thing was shown again to him, he was at as much loss to name it as before. It was noticeable that he was as well aware of his defect as we were, and evinced considerable annoyance at his failing memory.

I regret that $I$ am unable to state the character of his sense of smell, taste and color perception. From his inability to give the specific names of things, however, I doubt if this examination

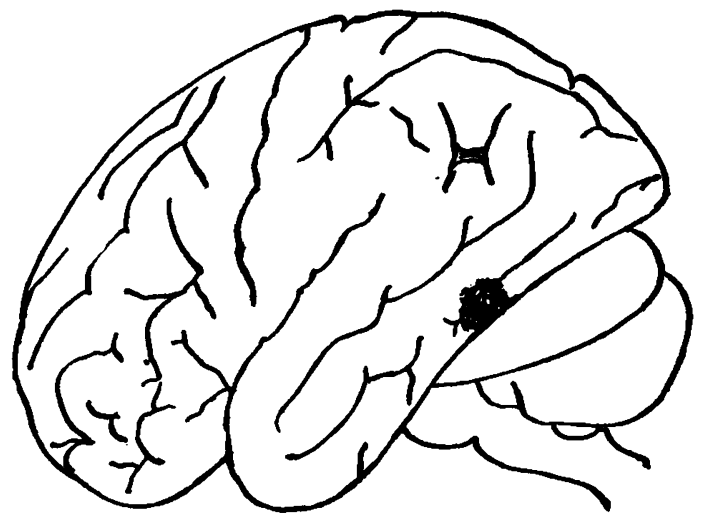

would have been very conclusive. No blood examination was made, but an analysis of the urine was reported negative.

During his stay in the hospital he showed no inclination to vomit. His headaches were for the greater part of the time less severe than they had been before admission, although no more morphia had been given. Attacks of very painful headaches, however, came on intermittently, generally most marked over the left side. Pressure over the left side of the skull revealed a point of great tenderness, about 3 inches above the tip of the mastoid; and deep pressure here provoked almost unbearable pain, which lasted 5 or 10 minutes. There was no tenderness anywhere else on the skull.

There was no motor aphasia, no agraphia, no psychical word-blindness or deafness, for he understood all written and spoken words. Apparently there was no marked impairment of word-memory when he attempted to write, for the examination of the 2 legal documents, drawn up but 5 days before, proved that. More extended tests in this direction were not made at the time of this examı- nation, and were not possible to make later. The evident defect was the patient's inability to name familiar objects.

Besides this anomia, the patient was unable in many instances to apply fitting adjectives, which depended, as it seemed, on the sound-memory for their use. He apparently recognized his mistakes and tried many times to correct them, but always without success. If the proper adjective was mentioned, however, he appreciated it at once.

It was evident from an analysis of these symptoms that the higher word-hearing memory centre was involved. Whenever he tried to recollect any name by referring, as it were, to his memory of the word as he had heard it, he failed. This was the conspicuous symptom, and the situation of the lesion which produced it was located in the left tempero-sphenoidal lobe, below the angular gyrus.

It was decided to wait a day, to make more extended observations, and to see if there might not be some improvement; but on Monday night the patient's headache was so severe, and his general condition was becoming so much worse, that it was agreed that the only hope of his recovery lay in the possible result of a surgical operation. Accordingly, on Tuesday a trephine opening was made over the superior temporal lobe, about one inch vertically below the angular gyrus, and over the point of tenderness marked out the day before. On removing the trephine button, a pulsating mass protruded about half an inch, and, on opening the dura, normal brain tissue appeared. The trephine opening was enlarged downward, and careful exploration of the brain beneath the surface was made with a needle in every direction, without discovering pus or other pathological condition.

It was then thought advisable to make another exploratory opening lower down, in the region of the cerebellum; not that the symptoms indicated it, but because it was the next point of election to locate an abscess extending from the middle ear. Accordingly, the skull was again trephined over the left lateral lobe of the cerebellum, but with negative results. The patient was by this time in such poor condition that further operative procedure was abandoned. The scalp wounds were hurriedly closed with silk sutures, and the patient returned to bed with all the symptoms of shock. He reacted, however, to stimulation, but gradually grew weaker, and died on the following day.

The post-mortem was made in a very hurried and imperfect manner, because the body was taken away on the earliest possible train, shortly after death. The mastoid portion of the temporal bone was removed, the antrum and cells of which were found filled with foul-smelling, inspissated pus, and the bone was for the most part necrosed. The brain was carefully sectioned, and found to be normal everywhere in appearance, except for an area in the posterior part of the left lower temporal convolution, where an abscess cavity was found, about the size of a walnut, filled with thick, foul-smelling pus of gelatinous consistency. Extending around this area, for a distance of about 
three-fourths of an inch in all directions, the brain tissue was found softer than elsewhere. Further examination of the meninges, other organs of the body, and particularly of the vessels of the skull, was not made. The writer was able to verify the above examination of the brain several days after its removal, and after it had been kept in formaldehyde solution. But the point of most interest was determined; namely, the location of a distinct lesion in the posterior part of the left lower temporal lobe, as indicated on the diagram.

The first trephine opening was made just above the position of the lesion, and presumably the needle had entered it at the time of the operation, but, owing to its gelatinous character, the fact was not discovered.

It is not the intention of the writer to enter into further speculative study of the case than has already been given. The cases reported by Mills, Hammond and Jack, in the articles mentioned above, are interesting for comparative study. This case is reported in the hope that it may add a little more to our at present rather imperfect knowledge of these higher auditory word centres. In offering this article, the writer regrets that a more careful and extensive pathological description of the case cannot be given.

\section{ON THE PASSING OF THE TREPHINE.}

BY ThOMAS H. MANLEY, PH.D., M.D., NEW YORK, Visiting Surgeon to Harlem Hospital; Professor of Surgery, New York School of Clinical Medicine.

Improvenest in mechanical technique occupies a prominent place in the recent marvelous advances in the art of surgery. It occupies a position of the first importance, though rendered possible only by the employment of anesthetics and antiseptics.

In this instance but a few brief notes will be submitted on improved and simplified operative technique in the management of fractures of the cranial vault.

From time almost immemorial the trephine was the instrument solely relied on for raising depressive skull fractures, and it is most remarkable, we will show, how several of our latest writers still recommend this antiquated and dangerous instrument; another illustration of the difficulty of casting aside the traditional teachings of the past.

For example, Treves, in describing the necessary instruments for dealing with fractured skull, mentions "the trephine-brush, a Hey's saw, a rongeur and a periosteal engine."1

Dr. Joseph D. Bryant says: "The patient is anesthetized, if not unconscious, preferably with chloroform; raise the periosteum with periosteotome, select a trephine of moderate calibre . . . push down the pin, etc." ${ }^{2}$

Dr. Lewis A. Stimpson pursues a similar course, and observes that " the trephine is employed only in cutting bone-flaps of large size... There is

\footnotetext{
1 Manual of Operative Suryery, 1900, ij, 211
}

2 Operative Surgery, 1899, p. 195, some reason to think that the jarring of the brain by the strokes of the mallet may be prejudicial." Dr. John Collins Warren of Boston, in no ambiguous terms, casts aside the trephine, and observes that "for elevation of depressed bone the trephine is very rarely needed; the sharp edge of a chisel can generally be inserted between some of the depressed fragments, and one after another they can be raised into position or removed." 4

Vidal, in a recent valuable contribution on craniotomy, dwells on the great value of the mallet and chisel as a substitute for the "ancient trephine," which, he well observes, bas no place at the present time in the therapy of cranial surgery. ${ }^{5}$

VARIETIES OF VAULT FRACTURE CALLING FOR SURGICAL INTERVENTION.

(1) Closed fracture, depressed or not; (2) open fracture, depressed or not; (3) fracture over the vascular areas - the sinuses; (4) fracture over the nonvascular areas.

After vault fractures the patient may or may not be unconscious. Our therapy must somewhat vary in children and adults.

DANGERS IN VAULT FRACTURES.

The dangers in fractures through any area of the calvarium proceed chiefly from two sources: (1) From the inherent effects, immediate or remote, of the traumatism; as shock, hemorrhage, disorganization of brain substance, or meningitis ; (2) from the effects of surgical procedure, the depression and toxemia of a pulmonary anesthetic, from hemorrhage, damage to the brain substance and sepsis.

OBJEC'TIONS TO THE TREPHINE.

In my early experience in the treatment of depressed skull fractures two patients' lives were lost by the employment of the trephine, - the sinuses were opened, mortal hemorrhage resulting; cerebral hernia was not uncommon from opening the meninges, and the violent propulsion of the cerebral substance under the extreme congestion of pulmonary anesthesia often led to subsequent hernia. The trephine serrations are cleansed with difficulty; in eburnated bone they are liable to break off; the skull's walls, being of an unequal thickness and oval in outline, are penetrated unequally by the ring-saw, so that while one segment of the instrument is yet engaged in the cranial wall, the other is ploughing through brain substance, or tearing open a great blood sinus; we are working in the dark. Perhaps at the moment we most need the instrument it is dulled or out of order; in any event, its employment frequently involves the employment of great force, and may exhaust more than one operator before the cranial cavity is opened.

It always involves the loss of the osseous covering of the brain, as the trephine button of bone

3 Operative Surgery, 1900, p. 196.

5 Thrombo Phlebite Du Sinus-Laterale, Arch. Prov. de Chirurg. Mai, 1901, p. 17. 